\title{
Towards contracting strategy usage for rework in construction projects: a comprehensive review
}

\author{
Q11 Ramin Asadi, Suzanne Wilkinson and James Olabode Bamidele Rotimi \\ School of Built Environment, Massey University, Auckland, New Zealand
}

\section{ABSTRACT}

Rework has been the core of attention for several years in the industry and academia as it affects the performance of projects. However, the trend of rework academic papers indicates an increasing rate in recent years; the overall research lacks a comprehensive review of the implemented theories and proposed models to explore further directions for rework management. Thus, to achieve a better understanding of rework it is necessary to perform an extensive review. This research aims to explore various insights from rework-related articles, discuss major research areas, and identify gaps for future studies looking closely at construction contracts. The selected articles are from three databases: "Scopus, Web of Science, Google Scholar". The findings are categorized into six study areas: sources of rework, models and solutions, management and strategies, theories and techniques, rework impacts, and factors affecting rework. The analysis of the employed techniques across these topics showed that System Dynamic Modelling, Action Research, Analytic Hierarchy Process, and Regression have been used more frequently than other methods. The comprehensive review also shed light on the new ways of thinking, analyzing, and controlling the impacts of the rework. This paper proposes the assessment of rework causes in the conditions of contract which provides opportunities for improvement of the construction contracts.

\section{ARTICLE HISTORY}

Received 21 March 2021

Accepted 6 November 2021

\section{KEYWORDS}

Construction management; contract conditions; project performance

\section{Introduction}

Academic published papers concerning rework in construction are critical as rework affects the performance of projects. Performance is one of the topics discussed more than others in construction projects ( $\mathrm{Yi}$ and Chan 2014). Different research studies worldwide have confirmed that rework represents a relatively large proportion of cost overruns (Love and Sing 2013, Simpeh et al. 2015, Eze and Idiake 2018a). Rework has been considered as the contributing factor to the schedule overrun and delay in projects, low profits, losses in terms of labour productivity, parties' dissatisfaction, and the arising contractual claims (Al-janabi et al. 2020). Rework has been at the core of attention both in theory and practice. Thus, various rework reduction and prevention methods with different data analysis methods have emerged over the last few decades. The integration of such diverse literature on rework issues provides a better understanding of the topics and advances more precise research in the future. Achieving in-depth insight into the rework research trends can be accomplished through a comprehensive review of the relevant literature. In alignment with the previously researched reviews (Sommerville 2007, Love and Smith 2018), the comprehensive analysis of rework studies that cover the life cycle of construction projects identifies the underlying requirements as well as the other possible solutions. The integration of the literature on rework assists construction policymakers to develop more robust methods.

Rework is considered as a none-value adding activity and the control of rework has been regarded as a great concern in the construction process. Failure in dealing with rework in the life cycle of projects leads to the unsuccessful delivery of projects. Therefore, rework management needs to be considered throughout the entire process of construction projects. Within the rework research, various areas have been examined to identify sources of rework, measure the impacts of rework, and propose models and solutions for construction projects. For example, Zhang et al. (2018) introduced a conceptual rework management learning framework to identify the significant factors in three case studies in China. Alternately, research 
conducted by Love et al. (2018a) studied the theory of functional stupidity to better understand the barriers in rework mitigation. Research conducted by Ma et al. (2019c) advised project managers to determine rework in their daily practices by testing a novel method of a critical chain design structure matrix for the purpose of scheduling. Some other studies introduced rework as the result of a lack of knowledge, which is a reality, and it is partly due to a lack of understanding of the project manager or contractor about rework (Love et al. 2019a).

Summarizing rework research studies is a necessity to suggest new recommendations. This paper presents an overview of the studies that have critically reviewed the relevant topics around rework in the construction industry, including concepts, causes, impacts, and adopted rework mitigation strategies from 1990 to 2020. The comprehensive review identifies the unexplored research areas and defines the state of the art and trends of rework research studies. The paper result as shown in Table 2 revealed that the selected period was an appropriate time span to review rework papers as it includes the majority of rework publications. Furthermore, previous studies have also pointed out that rework problems have been exposed over the last 25 years (Love et al. 2018a), thus the selected period suitably covers the development of rework research in the construction industry.

The essential step of rework management is the identification of rework sources as it assists practitioners to analyze the impacts of rework. The identified rework causes are used for assessment, analysis, and for the purpose of proposing models, solutions, and adopting strategies. This review reveals new approaches to develop the body of knowledge and helps practitioners improve rework practices in construction projects. The paper intends to contribute to rework management in the construction industry by addressing the study's objectives including (a) addressing the study areas of rework (b) classifying the impacts of rework (c) categorizing the implemented theories, proposed models, and developed strategies for better understanding and easy referencing, and (d) identifying research gaps and providing suggestions for future research directions.

\section{Overview of rework in construction}

The Construction Industry Development Agency (1995, $p$ 59) described rework as an "activity that involves doing something at least one extra time due to non- conformance to the requirements." Since there was no precise definition for rework in the construction industry before this statement, some other terms can be found in the literature that is similar in wording. Using interchangeable words, such as deviation, change, error, omission, defect, failure, damage, repair, nonconformance, and snag, not only have led to a lack of uniformity in the definition of rework, they have also affected the measurement methods, data collection and comprising strategies (Love and Smith 2018). Various definitions can be found in the literature (Robinson et al. 2004, Hwang et al. 2019), but Love and Smith (2018) simplified it as a verb that means to revise or work again. Although different definitions are given for illustrating the concepts of rework in construction projects, a common understanding exists on the key steps of reworking. The process includes identifying the source of rework, analyzing the impacts of rework, providing a rectification model, removing the incorrect work, and re-building.

Despite the significant amount of identified rework factors that improve projects' performance, rework remains a real challenge in the construction industry (Love and Smith 2018, Al-janabi et al. 2020). While the occurrence of rework is related to the nature of the construction industry in splitting the entire work among various parties in the supply chain (Simpeh et al. 2015), the continuity of rework in construction projects may result from the implicit ignorance of rework by practitioners or organizations ( $\mathrm{Ma}$ et al. 2019a) that is called "uncomfortable knowledge" (Love et al. 2019a). A range of solutions has been placed in two categories of reduction and prevention models to manage rework in construction projects. The former is once rework has occurred whereas the latter involves the process that prohibits rework from taking place. Nonetheless, while various models have been proposed through the years, there is limited research that has been able to identify a comprehensive way in which rework can be entirely controlled (Love et al. 2016a). Without implementing a systematic approach that enables participants to trace rework causes on the overall process, the occurrence of rework cannot be actively reduced or prevented (Palaneeswaran 2006, Zhang et al. 2018). Thus, it is time to shift the mindset towards critical thinking regarding why rework occurs and how it can be managed systematically even though there is no standard available to describe the characteristics of rework (Love and Smith 2018). One of the contributions of this study is facilitating the development of new approaches in rework management. 


\section{Methodology}

This paper presents a comprehensive review of mapping rework and the development of rework management in construction projects. A literature review is widely used in many research fields to generate and refine research ideas for future studies (Xia et al. 2018, Tezel et al. 2020). The review enables researchers to fit their research project into a broader context through the verified findings (Dixit et al. 2019) and find out more about the research strengths and limitations (Dallasega et al. 2021). The basic steps of such reviews include the following sequences: identification of the needs, developing search criteria, searching databases, selecting the publications and quality assessment, result summarization, and reporting. A four-step methodology to meet the pre-mentioned sequences has been defined and employed in this paper as prescribed in Figure 1. The four steps facilitate research content analysis to develop an in-depth knowledge of rework. The four steps include a searching strategy to identify the browsed papers (Dallasega et al. 2021), document refinement to restrain the initial papers (Tezel et al. 2020), visual examination to select the final relevant papers for further processing (Xia et al. 2018), and data extraction and analysis (Schon et al. 2017).

This paper was undertaken based on conducting a comprehensive review and performing content analysis. A comprehensive review of the literature tends to depict the potential future research (Mohandes et al. 2019) which is the aim of this study. In addition, the aim of this study involves categorizing the research interest, the method used and the proposed models that can be achieved through content analysis. Content analysis is an inductive method to unfold outlines and organize the extracted data into groups (Ayodele et al. 2020). The search engine Scopus to recall high-impacted relevant published papers was selected to start the search process. The process was completed by adding two more search engines to ensure identification of all the rework published documents in construction. As an instance, the Scopus engine does not cover some journals, such as Project Management Journal (PMJ); furthermore, published papers of Engineering, Construction and Architectural Management (ECAM) before 2003 are not included in the Scopus extent (Hong et al. 2012). Thus, the other two search engines can cover these limitations.

Choosing the right keyword to retrieve the relevant papers is the key part of the search. As discussed earlier in the overview section, searching the other interchangeable words distracts from the result of rework trends in construction projects. Since the paper results are used for the assessment of the contract clauses in addressing rework issues, the keyword "rework" was

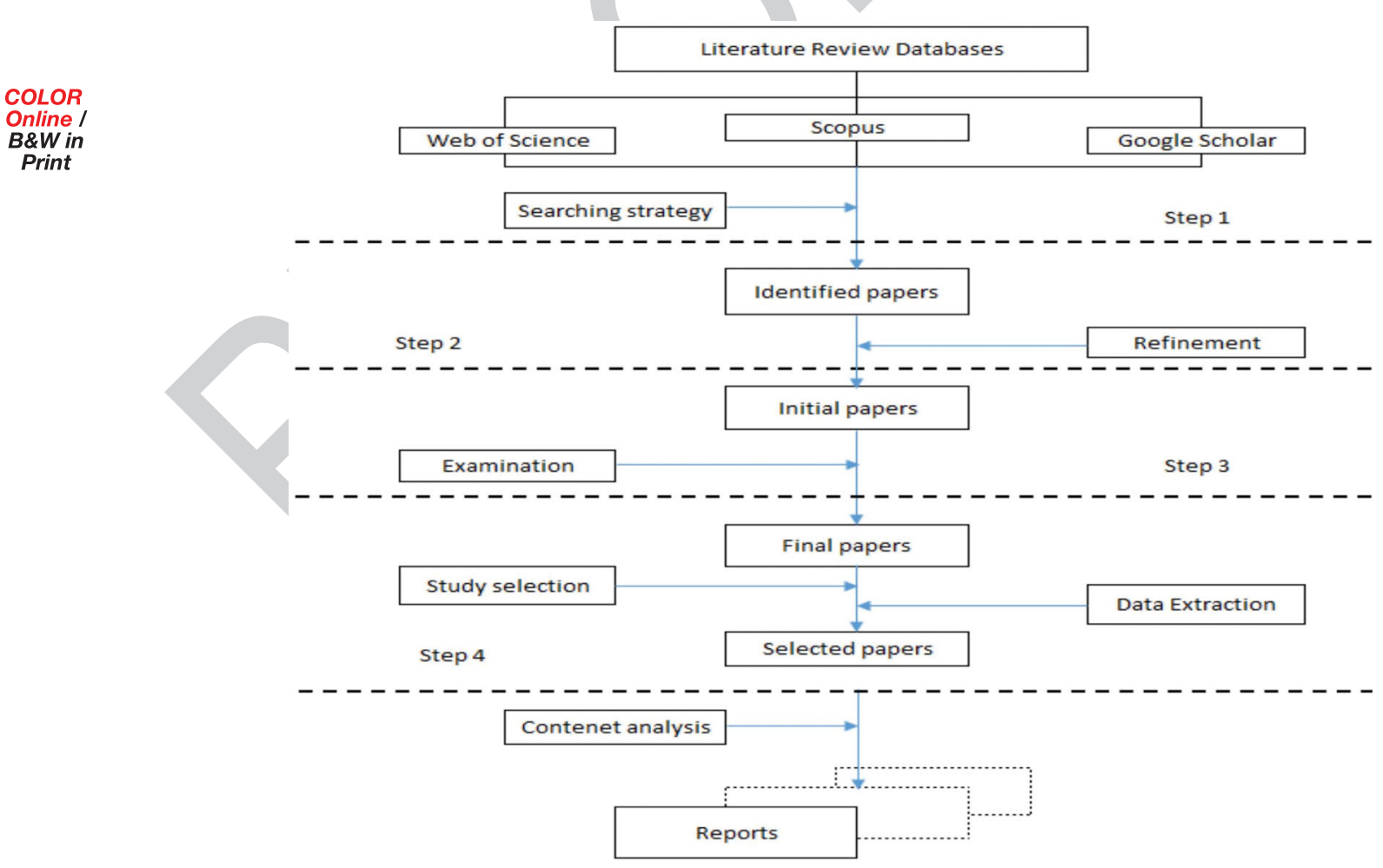

Figure 1. Four steps research framework. 
selected to search the literature. It is difficult to propose a general preventive measure to control rework as most of the previous studies have used rework along with other interchangeable words (Forcada et al. 2017, Ma et al. 2019a). Love et al. (2004) also claimed that there is a lack of uniformity in the rework data collection due to the various interpretations around rework. The diversity of interpretations due to the interference of the other words has led to a lack of uniformity in the rework data collection (Liu et al. 2020). The degree of ambiguity around rework increases as the other terms have been used interchangeably (Sommerville 2007). Therefore, to get an accurate and specific result aligned with the research aims the first keyword "rework" was selected. Furthermore, rework is a general word that is used in various industries, and to avoid any misleading by irrelevant documents from the other subject areas, the second selected keyword "construction" was used. The search engines then were used to find relevant publications as the following described sequence. The search space included only journals and conference proceedings.

\section{Searching strategy}

In step one, the first round of searching publications was launched under the keywords "rework" and "construction" to search the literature published in Scopus. The initial search for the selected period of 1990-2020 showed a total of 138 documents. The same process was repeated for the other two selected search engines. The second round of searching of the keywords in WoS revealed 106 documents during the same time period. Then the same scenario was repeated with the Google Scholar search engine. The third round of searching raised 170 documents. The advance search of Google Scholar is limited to two options: searching the keyword anywhere in the article and/or in the title of the article. The central message of the articles is conveyed through the title and this section is more likely exposing the articles' contribution to the theories around the searched topics (Larsen et al. 2019). Therefore, the keywords "rework" and "construction" were searched in the article titles. In summary, a total number of 414 papers were identified and collected by the end of step one.

\section{Document refinement}

However, the search was strictly limited to construction projects to exclude any unmatched papers; there were still some unwelcome publications that belong to other science fields. In the second step, more limitations were applied by refining the entire search process to eliminate the proportion of unrelated documents. The Scopus search engine was refined through three categories. The document type was limited only to the peer-reviewed articles and conference papers, the publication stage was narrowed only to the final documents, and the language was restricted only to English. The exclusion criteria included no full books, papers where the full text was not available, lessons learned, and recommendations or guidelines. This refinement resulted in 128 documents in the Scopus database. The same refinement was implemented into the Web of Science search engine, and the result showed a total number of 92 papers at the end. The third search engine of Google scholar has no features for refinement except for excluding the citation to eliminate the non-paper rows. Excluding the citation portion of Google Scholar dropped the number of papers down to 109 documents. In total, the refinement process constrained the number of papers to 329 documents as the initial papers for more consideration.

\section{Visual examination}

The next step was a visual examination to remove irrelevant and repeated documents with the same titles. Part of the initially identified papers may differ from the research scope; however, they met some of the search keywords' criteria. A more accurate selection of relevant papers will result in a more reliable conclusion, so the papers that did not satisfy the research criteria or those that were found to be totally unrelated to this study's scope must be excluded. The procedure of publications' examination was as follows:

(1) All papers' titles were reviewed initially to find out if they were really fitted to the research scope or not. The unfitted papers were removed.

(2) The abstract of all remaining documents was scanned and assessed, and the irrelevant papers were deleted to ensure that no more irrelevant papers were available

After these sequences, the following result was achieved. There were 46 irrelevant papers from Scopus; therefore, this search engine's final papers decreased to 82. This figure for Web of Science and Google Scholar was dropped to 64 and 88 as there were 28 and 21 irrelevant papers, respectively. In total, 
Table 1. Summary of papers number reduction process.

\begin{tabular}{lcccccc}
\hline Search engine & Step 1 & Step 2 & Step 3 & Common papers in Excel sheet & Final selected papers & Date of search \\
\hline Scopus & 138 & 128 & 82 & 0 & 82 & 14.04 .2020 \\
Web of Science & 106 & 92 & 64 & 54 & 10 & 14.04 .2020 \\
Google Scholar & 170 & 109 & 88 & 40 & 48 & 14.04 .2020 \\
Total & 414 & 329 & 234 & 94 & 140 & - \\
\hline
\end{tabular}

234 papers remained as valid documents for further analysis.

\section{Study selection and data extraction}

The outputs of the three engines consisted of a total of 234 documents. Due to the high number of recorded studies, the Microsoft Excel program was used to efficiently manage the retrieved information. The Excel file included the following items to take the essential data out of the collected papers and provide required reports. All the collected papers were taken into consideration to carry out the data extraction process:

- Basic information of title, authors, and publication date (for checking the same papers)

- Location: country, university, research centre, or affiliations (for reporting the impacts in different regions)

- Aim of the study (for identifying different themes and categorization)

- The employed method and techniques, contributions, and result (for discussion and identification of further research direction)

Listing all papers in the Excel sheet and sorting them revealed that some papers were the same based on using the three search engines. To make sure that none of the collected documents are duplicated, the Scopus' results were compared to the other two search results in terms of paper title and authors. There were 54 mutual papers found between Scopus and Web of Science. Following that, the cumulative list was compared to the other documents from Google Scholar, and it revealed that there were 40 common papers. In other words, the Web of Science adds only 10 more papers to the retrieved documents from Scopus and Google Scholar added 48 more papers. The limitation of each search engine confirms that relying on only one search engine to analyze the rework contents will not result in a reliable conclusion. Thus, covering the missed papers in the other search engines was necessary, and this study has taken the benefit of this approach. In total, 94 papers were found to be similar in the Excel file and were removed to avoid misleading the analysis. By the end, 140 papers were left as the final selected papers for further processing. Table 1 shows an extract from this reduction process in selecting the final papers.

\section{Results of the content analysis}

Friedrich et al. (1987), initiated the basis of research on rework topics into two general categories of "developing a systematic technique for counting rework" and "using a method that accounts for the effects of rework to measure the actual status of the project". Thus, the following subcategories had considered summarizing the research topics (a) to find out the origins of rework, and (b) to control the effects of the rework. This classification scope was then expanded into a wider area. Zhang et al. (2012) have described these directions and raised the area of rework studies into two clusters of "rework as a quality issue" and "the role of rework on performance". The first group of studies that have considered rework as a quality issue resulted in the emergence of broader research levels to identify the sources of rework through various methods. For example, it was used to treat rework events through the conventional approaches of TQM. The second group of studies attempts to focus on rework impacts on project performance, management practices, and the assessment of factors that affect rework. However, the research interest scope was not limited only to these major directions and later it was expanded.

The comprehensive review revealed that the rework subject in construction papers was repeatedly involved in (1) identifying rework causes (Love and Edwards 2004, Oyewobi and Ogunsemi 2010, Hwang et al. 2014, Forcada et al. 2017); (2) proposing models for reduction or prevention of rework occurrence (Love et al. 2000, Love et al. 2009, Simpeh et al. 2015); (3) providing recommendations and tactics for managing rework and strengthening available frameworks to achieve more benefits (Hwang and Yang 2014, Yap et al. 2017, Love and Curtin 2019); (4) implementing theories and using methods to facilitate rework identification, classification and mitigation (Robinson et al. 2004, Palaneeswaran et al. 2008, Hossain and Chua 2014, Ma et al. 2019c); (5) quantifying and measuring 
the effects of rework on project performance (Josephson et al. 2002, Hwang et al. 2009, Hegazy et al. 2011, Eze et al. 2018), and (6) evaluating some of the indicators that influence the occurrence of rework (Love et al. 2006, Mills et al. 2010, Oyewobi et al. 2011, Mahamid 2016, Hwang et al. 2019).

The paper results clearly show that research interests have continued to develop, and novel ideas have emerged. Some new methods and approaches, such as "functional stupidity theory" and "fuzzy set theorybased" have been introduced (Love et al. 2018a, Hwang et al. 2019) in comparison to the previous qualitative analysis. More focus has also been drawn to the human functions, concepts of learning, and the importance of safety. For instance, recent studies have recommended the approaches of system thinking and shifting mindset to control rework and errors (Love et al. 2018b, 2019b). Therefore, the previously defined categories by Friedrich et al. (1987) and Zhang et al. (2012) must be amended to evaluate the publications between 1990 and 2020. Following the previously introduced research interests and considering the selected publications on rework, six distinct groups of interests are identified as the main rework studies area as shown in Table 2.

Since the research is conducted to compare the results of previous studies, the adopted method for categorizing the topic interests will be an appropriate approach (Ke et al. 2009). All selected papers were reviewed in detail to link their study scope with one of the above-classified areas. If a paper covered more than one group, the closer one in terms of the theme has been considered. Within the last three decades from 1990 to 2020, publications in the construction field perceived an increasing trend in rework research studies. The following sections discuss the main area of studies on rework, existing gaps, and further required research with a project perspective.

\section{Sources of rework}

This group of papers has mainly introduced rework sources and identified a cluster of rework causes from different perspectives. The trend of studies on identifying rework causes indicates that this study area has been of interest for several years and remains an interesting topic in current studies (Love and Li 2000, Palaneeswaran 2006, Simpeh et al. 2011, Ye et al. 2015, Safapour et al. 2019, Liu et al. 2020). This group contains the largest number of publications among the reviewed papers that deal with the sources of rework. To identify the cause of rework, the papers

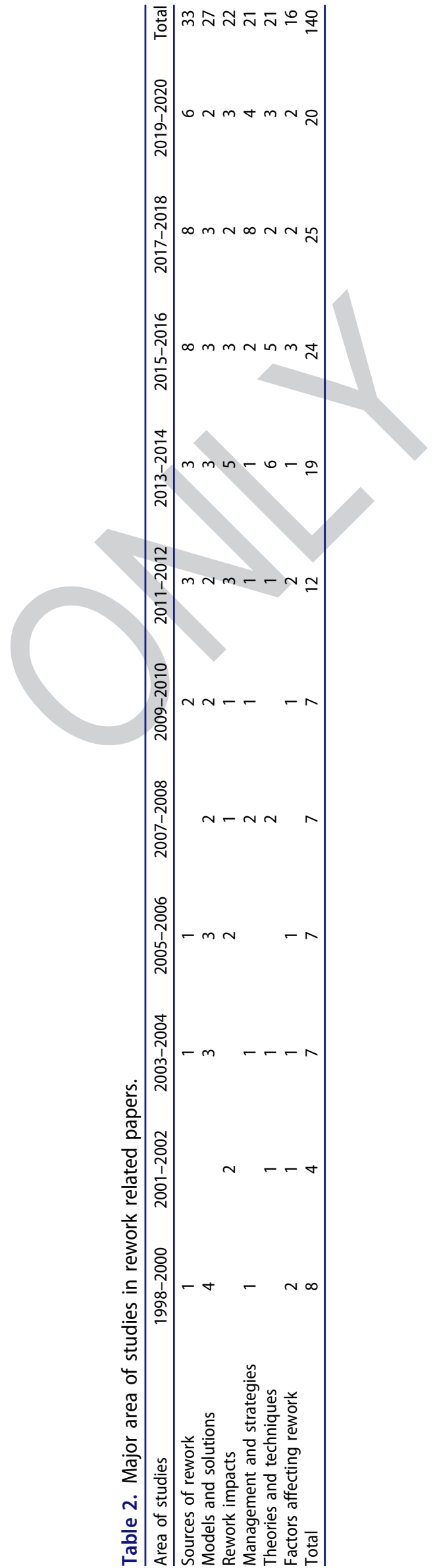


that were reviewed have studied various residential buildings, construction, and civil projects. However, the rework can be attributed to an array of complex, interrelated factors (Forcada et al. 2016) in many of the studies; changes, errors, quality deviations, damages, defects, failures, and omissions are referred to as the significant sources of rework (Palaneeswaran 2006, Ajayi and Oyeyipo 2015). Change as one of the main sources of a rework typically is generated from contract deviation (Love et al. 2005). Changes mostly result in variation and have the potential to raise disputes. An extensive literature review indicated that little research exists on the sub-topic of change and its relationship with rework (Love et al. 1999, 2002, Mahamid 2016, Kermanshachi et al. 2018). In contrast, many researchers have studied the sub-topic of error as the other significant source of rework.

Identifying and classifying the rework causes is the first step in rework management (Hwang et al. 2009). Some of the research that employed underpinning the theories for the in-depth study of rework causes was able to identify causal factors that explain how rework occurs (Love et al. 2010, Aiyetan 2013, Hwang et al. 2014, Forcada et al. 2017). Other studies that have provided a list of single casual factors have not explained the relational aspect of rework causes and have been unable to develop a mitigation framework (Li and Taylor 2014). Introducing the concept of "rework cycle" and using system dynamic tools led the other studies to a better understanding of rework interactions (Hegazy et al. 2011), then several studies were conducted to identify rework causes. Rework causes were classified to facilitate the proposed correction actions (Zhang et al. 2012). Depending on the research scope, several classification methods have been appearing for categorizing, measuring, and quantifying the identified rework cause. All introduced and used classification methods have typically been sorted in terms of the organizational body, such as client, consultant, designer, contractor, and subcontractor; or the key elements of the project, such as people, project, and organization; or stages of the project, such as design, planning and scheduling, construction; or management factors, such as project management and communication, site management, quality management, and contract management; or other aspects, such as process and changes, technical, machines, materials, external factors, and technology.

Throughout the past three decades, numerous rework causes have been introduced based on a review of several studies (Josephson et al. 2002, Love et al. 2009, Ajayi 2017, Enshassi et al. 2017, Ndwandwa et al. 2017, Eze et al. 2018, Safapour et al. 2019). Apart from that, using various versions of identified causes in different settings over the years, a long list of root causes has been compiled. Providing a list of all the identified rework root causes requires a systematic literature review and further content analysis. Consequently, there is a considerable amount of effort involved to identify rework causes at different stages of projects, so a general measure to prevent rework has not been defined yet (Ma et al. 2019a) because it is believed that rework studies cannot be compared due to a lack of uniformity (Palaneeswaran et al. 2008). The comparison of various introduced classification methods showed that the cluster titles are the same, but most of the root causes under each cluster vary, as each study follows different definitions.

\section{Factors affecting rework}

This group of studies has identified and assessed certain factors to determine whether the extent of rework occurrence is affected or not. Understanding the factors affecting rework helps researchers to provide better models and solutions for rework management. Searching the affecting factors of rework is an appropriate way to find opportunities for improvement. Most of the researchers in this group have first conducted literature reviews to determine the factors and then assessed them through question surveys and interviews. This group of papers has evaluated the factors affecting rework through various civil, construction, and residential building projects. An extensive literature review into this study area indicated that research on factors affecting rework covers only a small portion of possible variables so more investigations are required. The following factors have been assessed under rework circumstances; site supervision (three studies), project type (two studies), procurement method, organization size and the use of quality assurance, systems organizational learning, contract documentation, labour controls, change order, organizational culture, work ethic culture, labour productivity, visualization, BIM and technology (each in one study). However, three more factors from other study areas can be added to the list of factors affecting rework, such as waste material, the role of project team members, and the role of the supply chain.

Despite the initial finding that showed no relationship between project type and selected procurement method with cost and time performance (Love and Edwards 2005), there is some evidence confirming that rework is influenced by project type, location of 
the project, and the type of contract (Forcada et al. 2016). For instance, civil infrastructure projects experience less rework compared with building projects (Love et al. 2010), and rework in green building projects is lower compared with other conventional building projects (Hwang et al. 2016, Salihu and Babarinde 2020). The application of technology also is the other factor that has been the core of discussion and debates over the years. However, advanced technology, such as BIM and visualization may reduce design errors (Li and Love 1998); their implications need to be assessed within a clear perspective and defined project management process (Love et al. 2016a). Therefore, using technology without considering the other conditions of the project may not ensure the reduction of rework. In other words, this topic still requires more investigation in future studies.

\section{Rework impacts}

This group of papers has mainly focussed on rework effects by quantifying and measuring rework impacts, such as time overruns and cost overruns. Rework plays a critical role in the construction industry as it deals with the performance of projects. From this point of view, many studies have connected their research on project performance or construction performance, mainly through means of cost, time, and quality. However, while a critical review of the selected papers showed many concerns around this area of study, only those papers that directly assessed or analyzed the impacts of rework have been clustered in this group. In addition to the time and cost impacts of rework, several other factors also have been identified as the consequences of rework that affect people, projects, and organizations. The other identified effects of rework are listed below (Love and Edwards 2004, Love et al. 2004, Palaneeswaran 2006, Aiyetan 2013, Eze and Idiake 2018a):

(1) Psychological well-being of individuals, such as employees' demotivation, stress, dissatisfaction on the part of the project team, the low morale of workers, absenteeism, fatigue, and dissatisfied customers.

(2) Projects measures, such as quality degradation, unsafe structures, poor contract management, contractual claims and disputes, additional materials and resources, wastage handling, loss of profit/revenue, and lower performance.

(3) Organizational factors, such as battered reputation, reduced market share and loss of business, increased professional fees and financial difficulties, inter-organizational conflict, litigation, extra charges due to additional workforce and supervision of manpower, turnover of management, and lower productivity.

Each of these three groups of effects has an interaction with the others and, most importantly, each has cost impacts that are not measured by the organizations. Therefore, the total rework cost in construction projects remains relatively unknown (Love et al. 2019b). Due to the nature of the performance-oriented construction industry, most of the research in this area of study has focussed on measuring the two crucial factors of cost and time. An extensive review of the literature indicated that various costs and time reports could be found within the selected papers. The broad range of rework costs reported in both types of residential building projects and civil and construction projects is due to the diversity of rework definitions, which affects the scope of rework consequences and a variety of measuring methods (Love and Curtin 2019, Zhang et al. 2018). The indirect cost of rework has not been included in many of the reported costs. Taking this proportion of rework cost into account depicts how rework influences the performance of the project. More details of all previously reported rework costs are presented in Table 3.

In addition, the time impacts of rework have been reported in different ways and so their results are diverse. There is a difference in the reported delay that originated from rework as each research study follows different methodologies; for instance, a case study is showing a $4.1 \%$ delay of project duration while the question survey shows a $5.18 \%$ delay (Anjum and Azam 2019). Another question survey in the construction of building projects between 2005 and 2015 in Nigeria reported an average of a 7.35\% impact on the initial delivery time (Eze and Idiake 2018b). Case studies in Sweden have indicated that $7.1 \%$ of the total work time is required for correcting the rework (Josephson et al. 2002), while a single case study in Uganda showed $8.42 \%$ as the mean percentage of the rework-related impact on the project schedule (Kakitahi et al. 2016). Reports from 226 projects indicate more than three weeks' delay as the impact of client-related rework regarding time (Hwang et al. 2014). Besides, the contribution of rework in schedule growth was reported as $25 \%$ from 32 companies (Hwang and Yang 2014), while the mean schedule growth reported by Love (2002) was $20.7 \%$. A study in Malaysia has also shown that the scheduled growth 
Table 3. Summary of reported rework cost from literature.

\begin{tabular}{|c|c|c|c|c|c|}
\hline Rework cost & Method of measure & Type of project & Country & Type & Source \\
\hline $\begin{array}{l}2.0-3.2 \% \text { of the total } \\
\text { project costs }\end{array}$ & QS, 100 projects & High-rise building & Indonesia & A & Alwi et al. 1999 \\
\hline $\begin{array}{l}3.15 \text { and } 2.4 \% \text { of the project } \\
\text { contract value }\end{array}$ & 2 Case studies & $\begin{array}{l}\text { Residential and } \\
\text { industrial } \\
\text { warehouse }\end{array}$ & Australia & A & Love and Li 2000 \\
\hline $\begin{array}{l}4.4 \% \text { of the } \\
\text { construction values }\end{array}$ & 7 Case studies & Construction projects & Sweden & A & Josephson et al. 2002 \\
\hline $\begin{array}{l}6.4 \% \text { (direct) and } 5.6 \% \\
\text { (indirect) of the original } \\
\text { contract value, } 12 \% \text { "Total } \\
\text { rework cost (TRC)" }\end{array}$ & QS, 161 projects & Construction projects & Australia & A & $\begin{array}{l}\text { Love } 2002 \text {, Love } \\
\text { et al. } 2004\end{array}$ \\
\hline $\begin{array}{l}5 \% \text { (direct) of the total } \\
\text { construction costs }\end{array}$ & $\begin{array}{l}\text { Online questionnaire, } \\
359 \\
\text { projects "database" }\end{array}$ & $\begin{array}{l}\text { Buildings, heavy, and } \\
\text { light industrial, } \\
\text { Infrastructures }\end{array}$ & - & A & Hwang et al. 2009 \\
\hline $10.29 \%$ of contract value & QS, 115 projects & Civil infrastructure & Australia & A & Love et al. 2010 \\
\hline $5.06 \%$ of the completion cost & $\begin{array}{l}\text { Database of } \\
25 \text { projects }\end{array}$ & New building & Nigeria & A & Oyewobi et al. 2011 \\
\hline $3.23 \%$ of the completion cost & $\begin{array}{l}\text { Database of } \\
25 \text { projects }\end{array}$ & Refurbished building & Nigeria & A & Oyewobi et al. 2011 \\
\hline $\begin{array}{l}2.93 \% \text { (direct) and } 2.20 \% \\
\text { (indirect) of the contract } \\
\text { value, } 5.12 \%(\mathrm{TRC})\end{array}$ & $\begin{array}{l}\text { QS, } 78 \text { firms' } \\
\text { participants }\end{array}$ & Construction projects & South & A & Simpeh et al. 2011 \\
\hline $\begin{array}{l}11.30 \% \text { of original } \\
\text { contract value }\end{array}$ & QS, 276 projects & $\begin{array}{l}\text { Construction and } \\
\text { engineering projects }\end{array}$ & Aus & A & Love and Sing 2013 \\
\hline $\begin{array}{l}10-15 \% \text { of the original } \\
\text { contract cost }\end{array}$ & QS, 86 contractors & Residential building & Palest & A & Mahamid 2016 \\
\hline $\begin{array}{l}0.5-3.7 \% \text { of the total } \\
\text { work value }\end{array}$ & QS, 47 housing & Residential building & Sri Lanka & B & Dahanayake et al. 2016 \\
\hline $\begin{array}{l}4.08 \% \text { increase in total cost of } \\
\text { the project at } 76 \% \\
\text { completion of duration }\end{array}$ & Single case study & Construction projects & Libya & B & $\begin{array}{l}\text { Al Zanati and } \\
\text { Bajracharya } 2017\end{array}$ \\
\hline $\begin{array}{l}2.75 \% \text { of the original } \\
\text { contract value }\end{array}$ & Case study & Building projects & Spain & B & Forcada et al. 2017 \\
\hline $0.39 \%$ of contract value & $\begin{array}{l}\text { Case study, } \\
346 \text { projects }\end{array}$ & uction projects & Australia & B & Love et al. 2018a \\
\hline $\begin{array}{l}1.85 \% \text { of the construction } \\
\operatorname{cost}^{\mathrm{a}} \\
2.1 \% \text { of the } \\
\text { construction cost }^{\mathrm{b}}\end{array}$ & $\begin{array}{l}\text { Case study } \\
\text { QS, } 22 \text { projects }^{\mathrm{b}}\end{array}$ & esidential buildings & Iran & B & Anjum and Azam 2019 \\
\hline $4.95 \%$ of the total project cost & $\begin{array}{l}\text { Multiple case studies, } \\
6 \text { projects }\end{array}$ & Residential building & China & A & Liu et al. 2020 \\
\hline
\end{tabular}

A: project rework, which includes scope changes and manufacturing errors off-site. In this case, rework is presented as a cost to the "project", and no distinction is made to who pays for the repeated works; B: construction rework, which excludes scope changes and manufacturing errors that arise offQ8 site and focuses on the costs to the contractor; QS: questioner survey.

due to rework is from 5.1 to $10 \%$ (Yap et al. 2017). Analysis of a project schedule through a simulation model confirms that lengthening house completion times incorporate rework influences (Arashpour et al. 2014).

\section{Theories and techniques}

This group of studies deals with theories and some techniques to identify rework causes or measure their impacts in the project's design and construction stage, with the purpose of better understanding the nature of rework. Using theories and implementing some tools and techniques commenced in 1999, it is still a concern. Current evidence of the recent articles on this study area shows that researchers are still exploring various techniques to acquire more details about the nature of rework in the construction industry ( $\mathrm{Ma}$ et al. 2019b, Hwang et al. 2019). The increased number of publications in this area is attributed to the need to acquire deeper knowledge around rework. The identified theories and techniques have been implemented and tested in both civil construction and residential building projects. The core methodology used in this group of studies depends heavily on the questionnaire survey and interview followed by case studies. The more frequently employed tools and techniques in rework papers include system dynamic (SD), regression and multiple regression analysis (RA), analytic hierarchy process (AHP), and action research (AR). Some of the techniques that have been utilized along with their implications in rework papers are listed in Table 4. The other tools and techniques used include cause and effect, multi-domain matrix, retrospective sensemaking, partitioning algorithm, tipping point dynamics, and the functional stupidity theory. 
Table 4. List of employed techniques in rework management papers between 1990 and 2020.

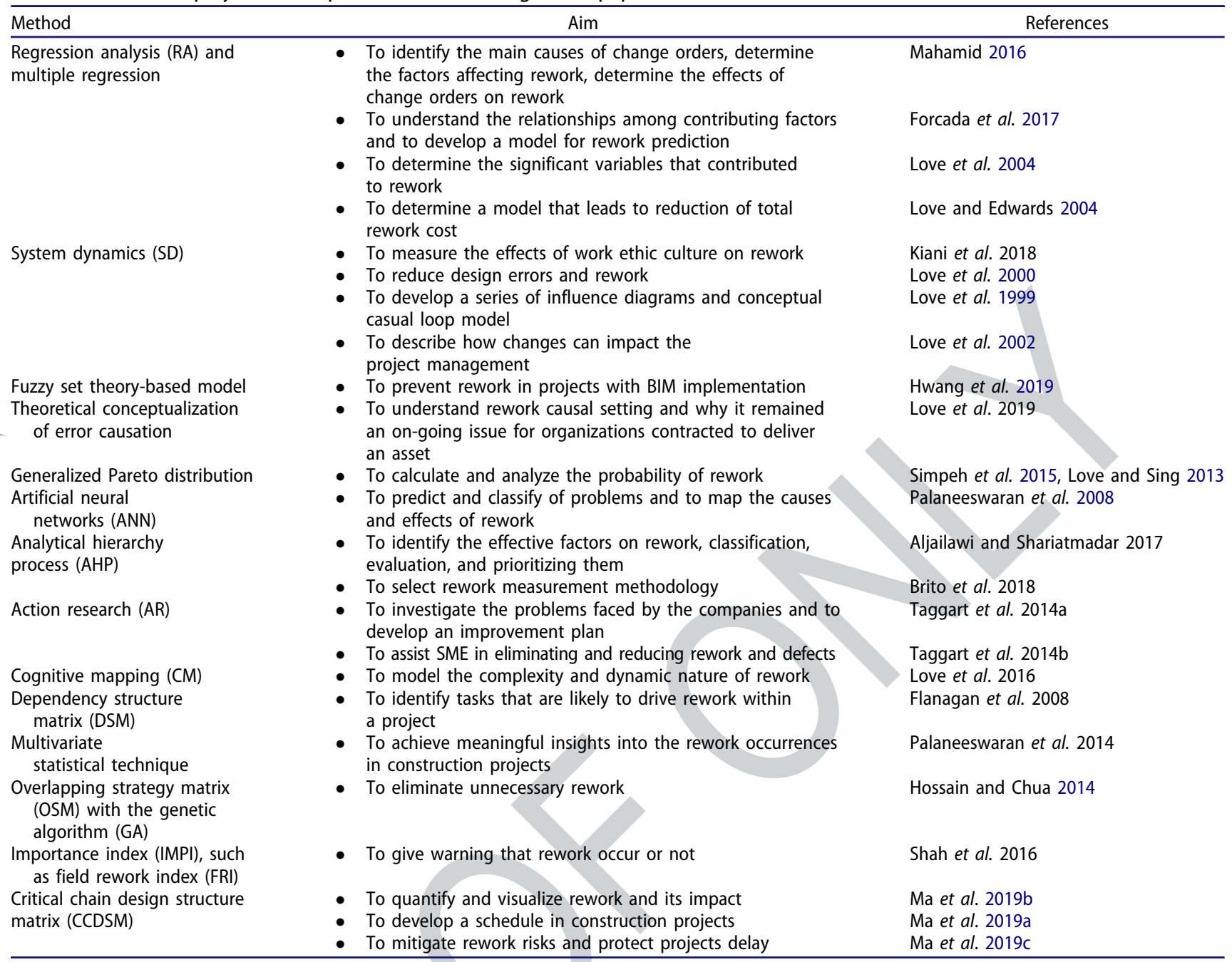

\section{Models and solutions}

The core of study in this group of papers has concentrated on design models and proposed solutions that mostly attempt to mitigate rework. The proposed models and solutions can be found in 17 papers on construction and civil projects, and seven papers on residential building projects. The effectiveness of the proposed models has been tested over the years by monitoring various project aspects, such as supply chain, design, quality, risk, technology, and learning process. All the submitted models that are listed in Table 5 provide an entire picture of what has been done to date. The proposed solutions throughout the reviewed articles also are presented after the table:

- The set-based concurrent engineering approach to mitigate design rework risk (Arundachawat et al. 2009).

- The risk classification matrix provides a frame of reference to mitigating future rework in complex projects (Love et al. 2011, Love and Edwards 2013) and risk management approach (Puspita et al. 2019).

- The time-cost trade-off to an optimum overlapping degree of design activities reduces change and rework (Dehghan and Ruwnapura 2014).

- Conceptual learning framework for program alliances confronted with rework (Love et al. 2015).

- Preventive Planning Tool (PPT) to identify rework causes and to plan preventive actions (Hamilton et al. 2018).

Recent evidence shows that the occurrence of rework has not been reduced effectively over the past few years even though various models and solutions have been proposed. A reduction model works effectively if organizations quantify rework impacts in advance (Love and Edwards 2013). In terms of quantifying the impacts of rework, organizations must willingly acknowledge that rework occurs in their projects 
Table 5. List of rework management models over the period of 1990-2020.

\begin{tabular}{|c|c|}
\hline References & Applied models and their purposes \\
\hline Love et al. (1999) & $\begin{array}{l}\text { The conceptual model for benchmarking and reducing rework throughout the quality-chain and to develop a } \\
\text { series of metrics for the causes and costs of rework using different procurement methods in building } \\
\text { construction projects }\end{array}$ \\
\hline Love et al. (1999) & $\begin{array}{l}\text { The conceptual model for improving the effectiveness of the supply chain and minimizing the incidence of } \\
\text { rework in building construction projects }\end{array}$ \\
\hline Love et al. (1999) & $\begin{array}{l}\text { Conceptual causal loop model to identify the major factors that influence rework and understand the casual } \\
\text { structure of rework influences }\end{array}$ \\
\hline Love et al. (2000) & $\begin{array}{l}\text { Design construction reduction model (DECOREM) to understand the factors that influence the occurrence of } \\
\text { design errors }\end{array}$ \\
\hline Love and Edwards (2002) & Reduction model that leads to reducing of the total rework cost \\
\hline Love and Smith (2003) & Generic framework for benchmarking rework at interfaces of the project's life cycle \\
\hline Love et al. (2004) & $\begin{array}{l}\text { Holistic reduction model to determine the significant variables that contributed to rework in building } \\
\text { construction projects }\end{array}$ \\
\hline Love et al. (2005) & $\begin{array}{l}\text { Pragmatic model for reducing the incidence of rework by the development of TQM culture in a structural steel } \\
\text { supply chain of residential buildings }\end{array}$ \\
\hline Palaneeswaran et al. (2006) & Artificial neural network model for mapping rework related impacts \\
\hline Sommerville (2007) & Analytical model to characterize, evaluate and inform decisions about defects and rework in new houses \\
\hline Love et al. (2008) & Systemic causal model for design-error-induced rework in a commercial construction project \\
\hline Love et al. (2009) & Generic structural model to identify the most significant causes of rework \\
\hline Zhang et al. (2012) & $\begin{array}{l}\text { Generalized model for rework reduction program (RRP) by managing a continuous improvement loop with four } \\
\text { functional processes }\end{array}$ \\
\hline Forcada et al. $(2014,2016)$ & $\begin{array}{l}\text { Rework generic systemic model to categorize causal variables adopted through project, organisation, } \\
\text { and people }\end{array}$ \\
\hline Simpeh et al. (2015) & Rework probability model to determine rework before the commencement of construction \\
\hline Ji and AbouRizk (2018) & Simulation model to quantitatively assist decision support systems in quality induced rework cost estimation \\
\hline Zhang et al. (2018) & $\begin{array}{l}\text { Conceptual rework management learning framework (CRMLF) which consists of people, approach, process, tool } \\
\text { and project environment to the analysis of rework management learning process }\end{array}$ \\
\hline Rezahoseini et al. (2019) & Model of TQM and BIM to identify the capabilities of BIM that can reduce rework in the projects \\
\hline
\end{tabular}

(Love and Smith 2018). Thus, proposing models and solutions in future studies must focus on those aspects of rework management that facilitate identifying and controlling rework. Specifically, more attention needs to be focussed on the early project stages, such as design and contracting and it should also consider human resources factors with a higher priority.

\section{Management and strategies}

This group of studies comes with recommendations that are usually considered the organizations' strategy to manage rework. There is an increasing rate of published papers on management and strategy during the years 2015-2020 compared to earlier years. More than $50 \%$ of papers in this area of study have been published in the last five years after 2015. The lack of effective proposed models and solutions has motivated researchers to shift their minds towards management and strategies. Publishing papers on the study area of management and strategies between 2015 and 2020 is higher, about twice that of the study area of models and solutions. In terms of project types, research in this area of study includes both civil construction and residential building projects. The nature of the suggested management and strategies differs widely in scope and content. The strategies used for the reduction or elimination of rework are very diverse. Hereafter, based on the review of the literature the most emphasized strategies and management practices to tackle the rework issues have been presented.

Quality management practice, benchmarking system, reinforcing supply chain relationships, lessons learned, risk management, change management, safety management, authentic leadership, error management, constructability, multidisciplinary design team, procurement strategies, learning from error, cost management, organizational learning, integrated design process, pre-project planning, front-end planning, materials management, dispute prevention, and resolution, utilizing building information modelling (BIM), design scope freezing, value management, use of information technology, supervisors' training, management commitment, the involvement of subcontractor/suppliers during the design stage, using relational contracting, and use of the Last Planner System approach, checking design drawings and verification. Some of these strategies have been implemented practically in previous studies and some need to be tested. While there was considerable interest in identifying rework causes and determining their consequences in the last several decades, it is time to think about developing the best strategies for managing rework.

\section{Discussion and research gaps}

Research on the various aspects of rework in the reviewed articles illustrates the complexity of rework 
issues that is a consequence of a faulty activity or process. The initial result of the comprehensive review showed that rework had been studied with different perspectives. Thus, it can be concluded that rework is an essential topic for the construction industry. Results showed that identifying the sources of rework is the most interesting sub-topic that generally ends with a classified cause of rework. The variety of presented categories of rework causes has pointed out that there is no commonly used classification method in construction projects. Since there is no systematic literature review on rework causes, performing a comprehensive review to unify all identified root causes of rework under a comprehensive classification model in the project life cycle is necessary. Studies that address the impacts of rework also provided insights into the implemented theories and techniques. Due to the inter-related influences of rework, several methods have been used in rework papers. Frequently used methods include regression analysis (RA) and multiple repression, system dynamic (SD), action research (AR), and the analytic hierarchy process (AHP). The implementation of more technical methods is of interest in recent years. Various data collection techniques were used to identify rework causes, while analytical methods were rarely implemented for assessing the impacts of rework due to their difficulty of use in practice (Dallasega et al. 2021).

The analysis of reviewed articles also revealed a range of proposed models and solutions for rework reduction and defined strategies for rework management. Part of the suggested models have been tested using case studies, yet the required level of project performance has not been achieved as rework is persisting in construction. Thus, the research moves towards implementing strategies rather than proposing models based on new project management concepts and advanced technologies. Contract documentation is one of the concepts of project management that covers the entire project life cycle. While there is some research that has studied procurement methods and contract documents in rework events (Love 2002, Love et al. 2006) the conditions of the contract under rework confrontation have not been explored in the previous studies. Thus, employing a strategy that evaluates the clauses of the contract in rework circumstances would bring novelty and will contribute to the body of knowledge. A contract is a legally binding document that governs all stages of a project and shares responsibilities between all project participants, so it is assumed that it plays a critical role in the process of reworking in an integrated manner.

It is important to understand what has been done regarding the contracts in the previous rework studies. An in-depth review of the sources of rework revealed that the contract document can be a potential source of rework occurrence (Love et al. 2003, Palaneeswaran et al. 2008, Forcada et al. 2014). As such, in the study by Love et al. (2006), they conducted research to investigate the effects of contract documentation in the incidence of rework. The main focus of the conducted research is on the quality of contract documentation/s in relation to the design consultants. Another research on the effects of rework in urban renewal projects in Colombia concluded that the type of contract is one of the triggers in rework occurrence (Forcada et al. 2017). While all this evidence shows the importance of the contract in rework incidences, up to now, as far as we can tell, few, if any, studies have assessed the conditions of the contracts in construction projects to tackle the rework phenomena. Based on a further review, factors affecting rework showed that very few studies have attempted to evaluate the influences of procurement methods on rework in construction projects. The result of the study conducted by Love (2002), indicated that the cost impacts of rework do not vary significantly among different procurement systems. Other studies that were conducted later claimed poor procurement methods as one of the main contributing factors of rework (Oyewobi and Ogunsemi 2010, Aiyetan 2013, Oyewobi et al. 2016). It is expected that the evaluation of contract conditions as the main output of a procurement system may result in a better understanding of rework.

Regarding the impacts of rework, many research studies have studied the cost impacts of rework as illustrated in Table 3. The value of the construction contract is affected by rework up to $15 \%$ or even more as reported in some cases. Having in-depth knowledge of rework costs may encourage researchers to investigate further how the causes of the rework could be eliminated. Current evidence shows how the research on the cost and time impacts of rework has saturated studies while measuring and quantifying the other rework effects has received less attention. Some of the other important rework effects, such as contractual claims and disputes, human influences, and safety, need to be considered more in the future. Furthermore, even though rework influences contractual claims and disputes, the literature shows that there is a scarcity of studies that assess rework in relation to claims and disputes (Palaneeswaran et al. 
2006). Lack of such studies may arise from the reluctance of the contract parties to scrutiny, which is referenced as uncomfortable knowledge in the study done by Love et al. (2019a). Thus, the assessment of the contract clauses of the construction projects in terms of addressing rework and its causes may result in fewer numbers of claims and disputes.

In addition, all the proposed models and solutions for reducing or preventing rework have been utilized during the design and construction stage of the project. Some studies pointed out that the proposed models and solutions can reduce the impacts of rework or predict the probability of a rework occurrence. They mainly cover the two stages of design and construction separately or jointly and in a few cases include the procurement stage of the project. The results revealed that none of the proposed models and solutions in the literature deal with the contract directly. Thus, a framework that deals with the conditions of the contract to tackle rework could prevent rework occurrence due to the early identification of the causes. Such a model also reduces the number of contractual claims and disputes in construction projects. Contract management is used as a tool for achieving the quality of work in construction projects (Coleman et al. 2020). Similarly, the contract is used for processing rework, even though it has not been employed and tested in the previous studies as listed in Table 5. A list of strategies that can deal with rework management has also been extracted from the literature. Among all the identified strategies, change management, dispute prevention, and resolution, procurement system, and relational contracting are linked to the construction contracts. The Construction Industry Institute (CII) has defined these strategies as the best practice to improve the performance of the project (Safapour and Kermanshachi 2019). While some research has studied change management to mitigate rework (Mahamid 2016, Kermanshachi et al. 2018, Love et al. 2019b), the content analysis revealed that the rework literature lacks implementation of the contracting-related strategies. All the evidence from a comprehensive review of the rework literature confirms that studying rework further in the contract documents is required.

Despite many efforts made to explore rework in construction projects, some gaps were identified through the literature review. Future studies will extend the existing knowledge, so further attempts to analyze any of the identified gaps will provide a higher understanding of rework processing and cover the research shortcomings. Some of the other gaps that were identified during this study are listed as follows:

(1) The lack of integrated research on rework in construction projects is one of the areas that need more attention. Rework causes are very complex and interrelated, therefore proposing a solution that is only relying on rework causes in one stage does not cover the project life cycle. Thus, integrating all rework causes into a platform consisting of the parties involved and all project stages could be an efficient way to conduct rework management in construction projects. Such studies can be started with a systematic literature review on rework causes to assess and unify previous classification models. Previous studies have adequately reviewed rework in the construction and design stages of a project but studying rework in procurement or tendering is very limited. Poor contract documentation has been identified as a major contributing factor to the occurrence of rework (Love et al. 2006). Assessment of contract documents to discover how a rework situation can be linked with procurement activities may fill the existing gap.

(2) The comprehensive literature review revealed that the number of studies on rework management across the construction supply chain is limited only to six papers. The rework process incorporates different project players, including client, consultant, designer, contractor, subcontractor, and supplier (Hwang et al. 2019). The collaboration of all these parties to achieve effective rework management is required. Thus, there are vast opportunities available for the future study of rework based on the perspective of supply chain management. Moreover, even though several theories, tools, and techniques have been employed in the rework literature, some of the concepts within the supply chain of construction projects still need more investigation, such as off-site construction, modular and prefabrication, lean construction tools and techniques, risk assessment and contract management strategies. The contract is a key element of supply chain management, and the contract conditions have not been studied under rework events yet. Only a few researchers have studied the interconnection of rework and contract documents. None of the study areas of rework dealt adequately with contracts and it is highlighted as a knowledge gap, 
while rework has adverse effects on contracts by generating claims and disputes.

(3) Future research can also work on the study of critical success factors and barriers. During the last 30 years, different models and solutions of rework management have been tested. Nevertheless, based on a review of the literature, no study could be found that has examined the critical success factors of the proposed models, therefore it is a suitable time to study these factors. Better implementation of future solutions will be possible once CSFs and barriers are identified.

(4) Many studies are still researching the traditional way for rework management, and there are very few if any studies that could be found using innovative solutions. Research on rework is expected to be incorporated with advanced tools and technologies. In recent years, BIM as an innovation management model shows great potential to decrease rework. However, such results need to be validated at least through some case studies. Exploring advanced technologies, such as using a cloud-based information flow or concurrently using BIM and other IT applications in future research is recommended.

(5) Transferring lessons learned from previous projects to the next project can prevent the occurrence of rework (Oke and Ugoje 2013). Lessons learned to activate the process of learning, which will enable the organizations to prevent rework (Love et al. 2015). Rework reduction in program alliances is an example of a successful model and can be used as a lesson learned. Program alliances facilitate learning through an organizational culture (Love et al. 2016b). Providing such cultures for cooperative learning instead of focussing on rework reduction may result in better achievement. Thus, future research could bring attention to learning theories and human resources, as rework basically is a product of human errors. Figure 2 shows the identified gaps and their relations to the construction contracts which need to be explored and validated in future studies.

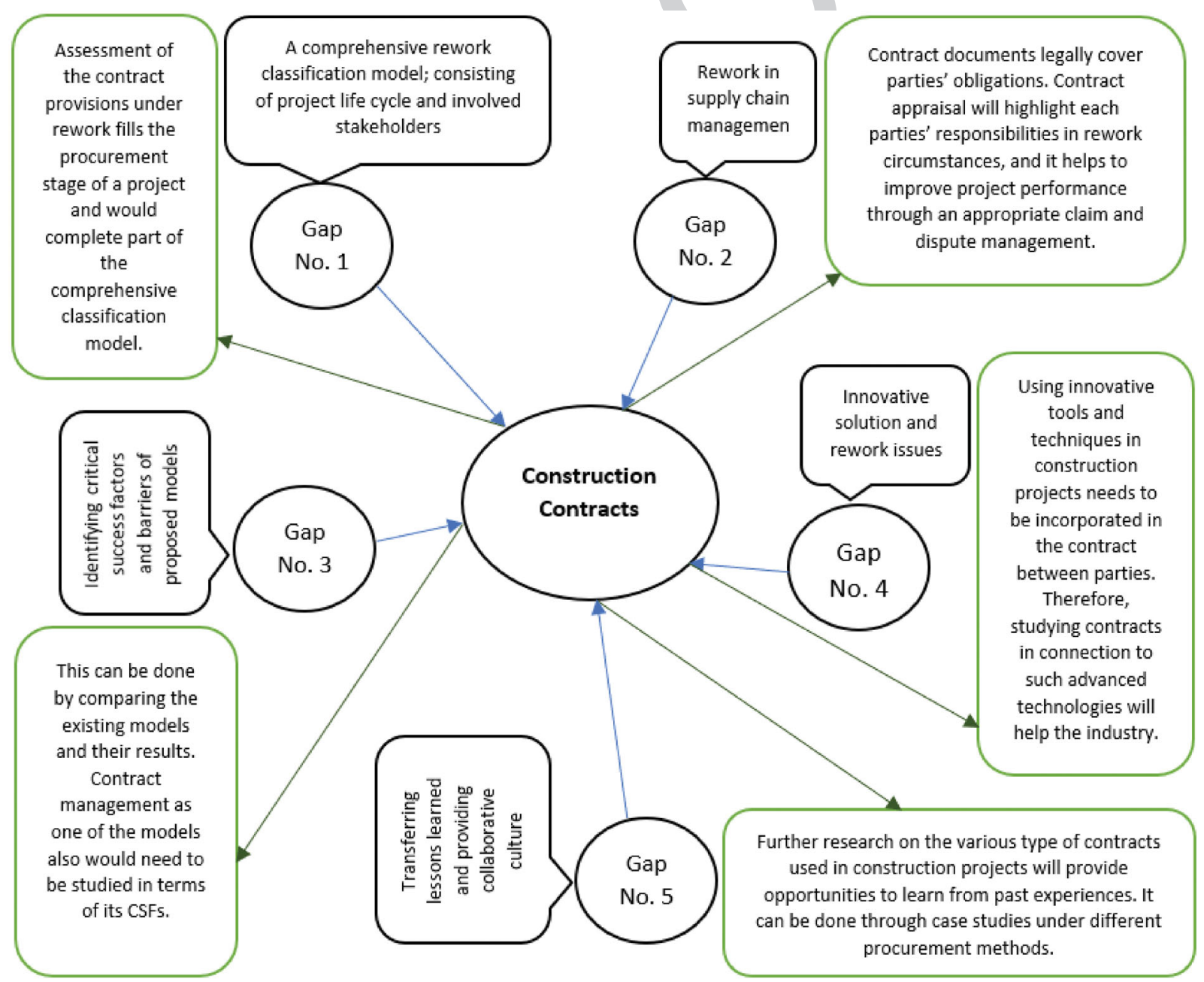

Figure 2. Identified gaps and their relations to construction, a diagram for future studies.

contract assification model; consisting appraisal will highlight each circumstances, and it helps to prove project performance ugh an appropriate claim and dispute management. 
Overall, the discussion section highlights the point that assessment of rework in the contract as the main output of any procurement system will result in a better understanding of the rework process by contract parties. It also will allow contract administrators to manage their contracts through rework-related provisions under the conditions of the contract. As such, a model that deals with various clauses of the contract can be proposed. This model will reduce conflicts as it gives more awareness to the contract parties at the early stages of the project, and therefore, the consequent claims and disputes will be appropriately managed. The same approach has been employed in some previous studies to manage change orders (El-adaway et al. 2016), safety issues (Abdul Nabi et al. 2020), back to back relationships (Assaad et al. 2020), disputes (Saseendran et al. 2020), time and delays (El-adaway et al. 2020). All these studies have investigated the conditions of the different standard forms of contract by comparing various clauses. The most commonly reviewed clauses of the contract in these studies are the extension of time, changes, claims, and dispute resolutions, payments, suspension and terminations, obligations and responsibilities, defects, and the engineer's power. Following a similar approach, the initial review of the commonly used standard form of contract in New Zealand showed that rework is linked to the clauses of variations, time extension, the engineer's power, defect liability, payments, disputes, and general obligations. However, more investigation by conducting surveys and professional interviews will validate such preliminary impressions. Therefore, further studying rework under contract conditions is suggested to achieve more details of the relations between rework and the targeted clauses of the contract.

\section{Conclusion}

The research aims to provide information on rework studies and identify knowledge gaps for further research in construction contracts through a comprehensive review. Based on a four-step literature review, rework papers from 1990 to 2020 were selected and analyzed in terms of research interests and their contributions to the body of knowledge. Hence, it has provided a platform to gain more useful information about rework concerns. The results showed that rework had been studied within six distinct research areas. The published papers mainly cover rework effects on project performance, rework causes and rework factors classification, strategies to manage rework either through reduction or prevention modelling, risks of rework, and recently the focus has moved more to safety concepts, learning, and human resources. A considerable proportion of rework studies have focussed on rework root causes, explaining that a great effort has been made to understand the nature of rework. Although identifying the sources of rework is the constant theme during the reviewed period, proposing models and solutions and implementing new strategies within a diverse perspective has attracted more interest in the most recent rework publications. A research model or commonly used solution for controlling rework cannot be generalized due to the variety of presented approaches. The analysis of rework research helps practitioners look for further collaborative research opportunities.

The paper has also identified some gaps for conducting future rework studies, such as the lack of an integrated method of mapping rework in the project life cycle, a lack of rework research in the procurement stage of the project, a lack of study on the critical success factors and barriers of suggested rework models, and there are also some other limitations. Therefore, new strategies are expected to emerge. Evaluating rework causes within the contract conditions could be a novel way to manage rework as the contract is an integrated document among the stakeholders of a project. It is suggested that rework needs to be considered at the early stages of the project as contract parties plan for the construction. Overall, construction commences after procurement, once the contract between parties is signed off. Conditions of the contract are an area that has not received much attention in rework research studies. Furthermore, due to the standard form of contract in most construction projects, the improvement process as it relates to contract conditions seems to have been neglected in the industry. Thus, considering the importance of rework issues at the time of contract preparation could be an effective way of monitoring rework. This paper suggests further studying of rework at the procurement stage of the project and contract is the main output of this stage. Rework also is a contributing factor to contractual claims, disputes, and conflicts among contract parties. Thus, rework can be used as a trigger for contractual improvement by providing a framework to manage contractual claims and reduce disputes. In other words, rework circumstances can be assessed in the conditions of the contract. Such assessment can cover the main related clauses, such as variations, time extension, defect liability, payments, engineers' power, and general obligations. The result of the 
contractual assessment provides recommendations for revising the contract's clauses and minimizing the loss in value that originates from the necessity to rework. Furthermore, the framework serves as a guide for adopting the condition of the contract. It also facilitates the development of more efficient approaches by decision-makers in the early stages of the project.

In sum, the approach used in this study is not without limitations. The lack of using the complex combination of similar keywords is the limitation of this study. This limitation can be justified by the inapplicability of studying all related publications in one review study. The main focus of the study is on the matters related to rework. Thus, the results are subject to the limited keyword of rework. The criteria for selecting the keywords may seem narrow for the unit of analysis, but the cross-check approach within three databases provided a wide range of related publications. The identified 140 papers included in the content analysis were deemed reasonable for extracting required information. Nonetheless, the employed approach is considered appropriate according to the study's aim to be aligned with the construction contracts.

\section{Disclosure statement}

No potential conflict of interest was reported by the authors.

\section{ORCID}

James Olabode Bamidele Rotimi (iD) http://orcid.org/00000001-6744-4683

\section{References}

Abdul Nabi, M., et al., 2020. Contractual guidelines for construction safety-related issues under design-build standard forms of contract. Journal of construction engineering and management, 146 (7), 04020074.

Aiyetan, A.O., 2013. Causes of rework on building construction projects in Nigeria. Interim, interdisciplinary journal, 12 (3), 1-15.

Ajayi, O. and Oyeyipo, O., 2015. Effect of rework on project performance in building project in Nigeria. International journal of engineering research \& technology, 4 (2), 294-300.

Ajayi, O.M., 2017. Occurrence of rework on components of building project in Lagos state, Nigeria. International journal of sustainable construction engineering \& technology, 8 (1), 84-93.

Al-janabi, A.M., Abdel-Monem, M.S., and El-dash, K.M., 2020. Factors causing rework and their impacts on projects performance in Egypt. Journal of civil engineering and management, 26 (7), 666-689.
Anjum, S., and Azam, F., 2019. Time and cost impacts of rework in building construction projects. Journal for innovative development in pharmaceutical and technical science, 2 (4), 74-84.

Arashpour, M., Wakefield, R., Blismas, N., and Lee, E.W.M., 2014. Analysis of disruptions caused by construction field rework on productivity in residential projects. Journal of construction engineering and management, 140 (2), 04013053.

Arundachawat, P., et al., 2009. Design rework prediction in concurrent design environment: Current trends and future research directions. In: Proceedings of the 19th CIRP Design Conference, Competitive Design, Cranfield University, 31 March 2009, 237-244.

Assaad, R., et al., 2020. Back-to-back relationship under standard subcontract agreements: comparative study. Journal of legal affairs and dispute resolution in engineering and construction, 12 (3), 04520020.

Ayodele, O.A., Richards, A.C., and Gonzalez, V., 2020. Factors affecting workforce turnover in the construction sector: a systematic review. Journal of construction engineering and management, 146 (2), 03119010.

Coleman, E., et al., 2020. Assessing contract management as a strategic tool for achieving quality of work in Ghanaian construction industry: a case study of FPMU and MMDAs. Journal of financial management of property and construction, 25 (1), 41-60

Construction Industry Development Agency 1995. Measuring up or muddling through: best practice in the Australian non-residential construction industry. Sydney: CIDA, 59-63.

Dallasega, P., Marengo, E., and Revolti, A., 2021. Strengths and shortcomings of methodologies for production planning and control of construction projects: a systematic literature review and future perspectives. Production planning \& control, 1-26.

Dehghan, R. and Ruwnapura, J.Y., 2014. Model of trade-off between overlapping and rework of design activities. Journal of construction engineering and management, 140 (2), 1-13.

Dixit, S., et al., 2019. Evolution of studies in construction productivity: a systematic literature review (2006-2017). Ain Shams engineering journal, 10, 555-564.

El-adaway, I.H., et al., 2016. Change order provisions under national and international standard forms of contract. Journal of legal affairs and dispute resolution in engineering and construction, 8 (3), 03716001.

El-adaway, I.H., Vance, R.A., and Abotaleb, I.S., 2020. Understanding extension of time under different standard design-built forms of contract. Journal of legal affairs and dispute resolution in engineering and construction, 12 (1), 04519031.

Enshassi, A., Sundermeier, M., and Abo Zeiter, M., 2017. Factors contributing to rework and their impact on construction projects performance. International journal of sustainable construction engineering \& technology, 8 (1), 12-33.

Eze, E.C. and Idiake, J.E., 2018a. Impact of rework on building project and organisation performance; a view of construction professionals in Nigeria. International journal of sustainable construction engineering \& technology, 9 (1), 29-44. 
Eze, E.C. and Idiake, J.E., 2018b. Analysis of cost of rework on time and cost performance of building construction projects in Abuja, Nigeria. International journal of built environment and sustainability, 5 (1), 56-67.

Eze, E.C., Idiake, J.E., and Ganiyu, B.O., 2018. Rework risks triggers in the Nigerian construction industry a view of built environment professionals. Independent journal of management \& production, 9 (2), 448-472.

Forcada, N., et al., 2016. Rework in urban renewal projects in Colombia. Journal of infrastructure systems, 23 (2), 04016034.

Forcada, N., et al., 2017. Factors affecting rework costs in construction. Journal of construction engineering and management, 143 (8), 04017032.

Forcada, N., et al., 2014. Rework in highway projects. Journal of civil engineering and management, 20 (4), 455-465.

Friedrich, D.R., Daly, J.P., and Dick, W.G., 1987. Revisions, repairs, and rework on large projects. Journal of construction engineering and management, 113 (3), 488-500.

Hamilton, L.M.J., José, R.F. F, Helder, G.C, and Pereira, V., 2018. Reduction of rework in complex projects - a preventive planning tool (PPT). In: Proceedings of the 2018 IISE Annual Conference, 1324-1329.

Hegazy, T., Said, M., and Kassab, M., 2011. Incorporating rework into construction schedule analysis. Automation in construction, 20, 1051-1059.

Hong, Y., et al., 2012. Critical analysis of partnering research trend in construction journals. Journal of management in engineering, 28 (2), 82-95.

Hossain, M.A. and Chua, D.K.H., 2014. Overlapping design and construction activities and an optimization approach to minimize rework. International journal of project management, 32, 983-994.

Hwang, B.G. and Yang, S., 2014. Rework and schedule performance; a profile of incidence, impact, causes and solutions. Engineering, construction and architectural management, 21 (2), 190-205.

Hwang, B.G., Shan, M., and Tan, E.K., 2016. Investigating reworks in green building construction projects magnitude influential factors, and solutions. International journal of environment research, 10 (4), 499-510.

Hwang, B.G., et al., 2009. Measuring the impact of rework on construction cost performance. Journal of construction engineering and management, 135 (3), 187-198.

Hwang, B.G., Zhao, X., and Goh, K.J., 2014. Investigating the client-related rework in building projects; the case of Singapore. International journal of project management, 32, 698-708.

Hwang, B.G., Zhao, X., and Yang, K.W., 2019. Effect of BIM on rework in construction projects in Singapore status Quo, magnitude, impact, and strategies. Journal of construction engineering and management, 145 (2), 04018125.

Josephson, P.E., Larsson, B., and Li, H., 2002. Illustrative benchmarking rework and rework costs in Swedish construction industry. Journal of management in engineering, 18 (2), 76-83.

Kakitahi, J.M., et al., 2016. Impact of construction-related rework on selected Ugandan public projects. Journal of engineering, design and technology, 14 (2), 238-251.

$\mathrm{Ke}, \mathrm{Y}$, et al., 2009. Research trend of public-private partnership in construction journals. Journal of construction engineering and management, 135 (10), 1076-1086.
Kermanshachi, S., Thakur, R., and Govan, P., 2018. Discovering the impact of late change orders and rework on labour productivity; a water treatment case study analysis using system dynamics modelling. In: Proceedings of Construction Research Congress, New Orleans, Louisiana, 691-701.

Larsen, K.R., et al., 2019. Understanding the elephant: the discourse approach to boundary identification and corpus construction for theory review articles. Journal of the association for information systems, 20 (7), 887-927.

Li, H., and Love, P. E. D., 1998. Visualization of building interior design to reduce rework. In: IEEE Proceedings, International Conference on Information Visualization, 31 July 1998, London, UK, 2-7.

Li, Y. and Taylor, T.R.B., 2014. Modelling the impact of design rework on transportation infrastructure construction project performance. Journal of construction engineering and management, 140 (9), 04014044.

Liu, Q., et al., 2020. Case based insights into rework costs of residential building projects in China. International journal of construction management, 20 (4), 347-355.

Love, P.E.D., et al., 2015. From individual to collective learning; a conceptual learning framework for enacting rework prevention. Journal of construction engineering and management, 141 (11), 05015009.

Love, P.E.D. and Curtin, J., 2019. Creating a mindfulness to learn from errors: enablers of rework containment and reduction in construction. Developments in the built environment, 1, 30001.

Love, P.E.D. and Edwards, D.J., 2004. Forensic project management; the underlying causes of rework in construction projects. Civil engineering and environmental systems, 21 (3), 207-228.

Love, P.E.D. and Edwards, D.J., 2005. Calculating total rework costs in Australian construction projects. Civil engineering and environmental systems, 22 (1), 11-27.

Love, P.E.D. and Edwards, D.J., 2013. Curbing rework in offshore projects systemic classification of risks with dialogue and narratives. Structure and infrastructure engineering, 9 (11), 1118-1135.

Love, P.E.D. and Sing, C.P., 2013. Determining the probability distribution of rework costs in construction and engineering projects. Structure and infrastructure engineering, 9 (11), 1136-1148.

Love, P.E.D. and Smith, J., 2018. Unpacking the ambiguity of rework in construction making sense of the literature. Civil engineering and environmental systems, 35 (1-4), 180-203.

Love, P.E.D., et al., 2018a. The praxis of stupidity an explanation to understand the barriers mitigating rework in construction. Production planning \& control, 29 (13), 1112-1125.

Love, P.E.D., 2002. Influence of project type and procurement method on rework costs in building construction projects. Journal of construction engineering and management, 128 (1), 18-29.

Love, P.E.D., et al., 2016b. Praxis of rework mitigation in construction. Journal of management in engineering, 32 (5), 05016010.

Love, P.E.D. and Li, H., 2000. Quantifying the causes and costs of rework in construction. Construction management and economics, 18, 479-490. 
Love, P.E.D., et al., 2010. Rework in civil infrastructure projects determination of cost predictors. Journal of construction engineering and management, 136 (3), 275-282.

Love, P.E.D., et al., 2009. Divergence or congruence; a path model of rework for building and civil engineering projects. Journal of performance of constructed facilities, 23 (6), 480-488.

Love, P.E.D., Edwards, D.J., and Smith, J., 2005. A forensic examination of the causal mechanisms of rework in a structural steel supply chain. Managerial auditing journal, 20 (2), 187-197.

Love, P.E.D., Edwards, D.J., and Smith, J., 2006. Contract documentation and the incidence of rework in projects. Architectural engineering and design management, 1, 247-259.

Love, P.E.D., Edwards, D.J., and Smith, J., 2016a. Rework causation emergent theoretical insights and implications for research. Journal of construction engineering and management, 142 (6), 04016010.

Love, P.E.D., et al., 2002. Using systems dynamics to better understand change and rework in construction project management systems. International journal of project management, 20, 425-436.

Love, P.E.D., et al., 2019b. Make or break during production shedding light on change orders rework and contractors' margin in construction. Production planning \& control, 285-298.

Love, P.E.D., Irani, Z., and Edwards, D.J., 2003. Learning to reduce rework in projects: analysis of firm's organizational learning and quality practices. Project management journal, 13-25.

Love, P.E.D., Irani, Z., and Edwards, D.J., 2004. A rework reduction model for construction projects. IEEE transactions on engineering management, 51 (4), 426-440.

Love, P.E.D., Li, H., and Mandal, P., 1999. Rework a symptom of a dysfunctional supply chain. European journal of purchasing \& supply management, 5, 1-11.

Love, P.E.D., Mandal, P., Smith, J., and Georgious, J., 2000. A design and construction rework minimization model. In: 1st International Conference on System Thinking in Management, 377-382.

Love, P.E.D., et al., 2019a. Making sense of rework and its unintended consequence in projects; the emergence of uncomfortable knowledge. International journal of project management, 37, 501-516.

Love, P.E.D., et al., 2018b. The costs of rework insights from construction and opportunities for learning. Production planning \& control, 29 (13), 1082-1095.

Love, P.E.D., Smith, J., and Han, S., 2011. Systemic rework risk classification for offshore projects. In: 27 Annual Association of Researchers in Construction Management (ARCOM) Conference, 1023-1032.

Ma, G., et al., 2019c. Critical chain design structure matrix method for construction project scheduling under rework scenarios. Mathematical problems in engineering, 2019, 1595628.

Ma, G., et al., 2019b. A critical design structure method for project schedule development under rework risks. Sustainability, 11 (24), 7229.

Ma, G., et al., 2019a. A novel method of developing construction projects schedule under rework scenarios. Sustainability, 11 (20), 5710.
Mahamid, I., 2016. Effect of change orders on rework in highway projects in Palestine. Journal of financial management of property and construction, 22 (1), 62-76.

Mills, A., Williams, P., and Yu, D., 2010. Benchmarking construction rework in Australian housing. International journal for housing science, 34 (3), 207-220.

Mohandes, S.R., Zhang, X., and Mahdyar, A., 2019. A comprehensive review on the application of artificial neural networks in building energy analysis. Neurocomputing, 340, 55-75.

Ndwandwa, S., Simpeh, E.K., and Smallwood, J.J., 2017. Factors influencing the occurrence of rework in construction. In: Proceedings of International Research, Sharping Tomorrow's-Built Environment, 757-770.

Oke, A.E. and Ugoje, O.F., 2013. Assessment of rework cost of selected building projects in Nigeria. International journal of quality \& reliability management, 30 (7), 799-810.

Oyewobi, L.O. and Ogunsemi, D.R., 2010. Factors influencing rework occurrence in construction; a study of selected building projects in Nigeria. Journal of building performance, 1 (1), 1-20.

Oyewobi, L.O., Falemu, O.A., and Ibironke, O.T., 2016. The impact of rework and organisational culture on project delivery. Journal of engineering, design and technology, 14 (2), 214-237.

Oyewobi, L.O., et al., 2011. Evaluating rework cost-a study of selected building projects in Niger state. Journal of geography and regional planning, 4 (3), 147-151.

Palaneeswaran, E., 2006. Reducing rework to enhance project performance levels. In: Proceedings of the One-day Seminar on "Recent Developments in Project Management, 1-10.

Palaneeswaran, E., Kumaraswamy, M.M., Ng, S.T., and Love, P.E.D., 2006. Neural network modelling for rework related cost overrun and contractual claims in construction projects. In: International Conference on Computing and Decision Making in Civil and Building Engineering, 14-16 June 2006, Montréal, Canada, 1393-1402.

Palaneeswaran, E., et al., 2008. Mapping rework causes and effects using artificial neural networks. Building research \& information, 36 (5), 450-465.

Puspita, A.W.Y., Suharyanto, A., and Indradi, W., 2019. Risk management rework and repair implementation phase in building project to improve project quality performances. International research journal of advanced engineering and science, 4 (2), 525-529.

Robinson, F.A., Dissanayake, M., and Campero, O., 2004. Developing a standard methodology for measuring and classifying construction field rework. Canadian journal of civil engineering, 31, 1077-1089.

Safapour, E. and Kermanshachi, S., 2019. Identifying early indicators of manageable rework causes and selecting mitigating best practices for construction. Journal of management in engineering, 35 (2), 1-13.

Safapour, E., Kermanshachi, S., and Taneja, P., 2019. Investigation and analysis of the rework leading indicators in construction projects state-of-the-art review. In: 7th CSCE International Construction Specialty Conference (ICSC), 12-15 June 2019, CON-294, 1-10.

Salihu, C. and Babarinde, S.A., 2020. Strategies for reduction of design-related rework in the Nigerian construction industry. PM world journal, IX (II), 1-11. 


$$
\mathrm{R}^{\mathrm{e}^{0^{0^{0}}}}
$$


Towards contracting strategy usage for rework in construction projects: A comprehensive review

\author{
Asadi, R
}

2021

http:/hdl.handle.net/10179/16870

22/04/2023 - Downloaded from MASSEY RESEARCH ONLINE 